\title{
LEGAL IMPLICATION OF PLACING THE GOOGLE BALLOON IN NATIONAL AIR SPACE
}

\author{
Cholifah Damayanti and Anjar Supriadhie \\ Center of Aeronautics and Space Policy Studies, National Aeronautics and Space Institute (LAPAN) \\ E-mail: ifahdamay@gmail.com
}

\begin{abstract}
The air space above the sovereignty of a state is closed to activities of other states except to get permission from the subjacent state. Challenges and problems in the development and utilization of national air space region tend to increase and require problem solving prevention. One of them is the American Google's plan to cooperate with Indonesian government to put Google Balloon over the In-donesian national air space. The legal implications of this Google Balloon placement become the fo-cus of this study through system legal theory and legal effectiveness theory. Based on the results show that First, from the legal substance aspect, status of Google Balloon cannot be categorized as an air or space vehicle; Second, viewed from the legal institutional aspects, the implementation of the project related to the competence of the relevant agencies which does not only involve the ministry of communication and information but also involve the parliament; and Third, from the legal culture aspect, socialization towards the plan of the project needs to be expanded to prevent any unfavorable circumstances.
\end{abstract}

Keywords: Balloon Google, legal implications, the National Air Space

\begin{abstract}
Abstrak
Ruang udara di atas kedaulatan suatu Negara tertutup bagi kegiatan Negara lain kecuali mendapatkan izin dari Negara kolong. Tantangan dan masalah pengembangan dan pemanfaatan potensi di wilayah ruang udara nasional cenderung meningkat dan menuntut adanya antisipasi pemecahan masalah. Salah satunya adalah rencana kerjasama antara Google Amerika dengan pemerintah Indonesia untuk menempatkan balon Google di wilayah ruang udara nasional. Implikasi hukum penempatan balon Google menjadi fokus dalam kajian ini melalui pendekatan teori legal sistem dan teori efektifitas hukum. Berdasarkan hasil analisis dinyatakan bahwa Pertama, dari aspek substansi hukum, status hukum balon Google tidak dapat dikategorikan sebagai wahana udara maupun antariksa; Kedua, dari aspek kelembagaan hukum, pelaksanaan proyek ini terkait dengan kompentensi instansi terkait tidak hanya melibatkan Kemenkoinfo namun lebih luas melibatkan DPR; dan Ketiga, dari aspek budaya hukum, sosialisasi terhadap rencana proyek ini perlu secara meluas, untuk menghindari hal-hal yang tidak dikehendaki pada masyarakat.
\end{abstract}

Kata kunci: balon Google, implikasi hukum, Ruang Udara Nasional

\section{Introduction}

The limited space of land and water as a basis for activities of life, and the interests of human effort to maintain continuity and improve quality of life lead to more intensive exploration of air space. Issues related to the air space emerged since human realized that air space as part of the universe is considered as one of the potential resources.

Indonesia, an archipelagic country, as mentioned in Article 4 of Government Regulation Number 6 year 1996 on waters, stated that the sovereignty of the Republic of Indonesia include air space over the territorial sea, archipelagic waters and inland waters. Regarding these conditions, Indonesia has a globally comparative advantages and economical usage potentials.

Economic activities that utilize air space and resources such as physical development activities, telecommunications, aviation/air transportation, broadcasting and industrial activities which utilize the air resources (wind power plant) and other activities will continue 
evolving as demands persistently grow. So far, these activities have contributed to the economic development. Moreover, as an archipelagic country, Indonesia requires further national air space resources development to facilitate access and information development to the entire territory of the country, especially areas that do not have adequate facilities of transportation and communication.

Challenges and problems in the development and utilization of the national air space potentials tend to increase and demand solutions nationwide. The violation of the territorial sovereignty of Indonesian air space, conflict of air space management in some border areas between Indonesia and neighboring countries are some examples of the existing problems to be the subject of discussion which remains unsolved. However, it cannot be separated from the consequences of legislation absence as legal basis of national air space regulation instead of aviation Law until present.

Reviewing the provision of international law affirmed in Article I of the Chicago Convention 1944, the Contracting States Recognize that every State has complete and exclusive sovereignty over the airspace above its territory. ${ }^{1}$ Thus, each State has exclusive jurisdiction and authority to control the air space above its territory. Activities in the air space of other countries have no right to enter the air space without its consent. ${ }^{2}$

In regard to this, the upcoming and considerable challenges on its management in Indonesia is a problem related to the implementation of cooperation plans of Google Inc. with Indonesian telecommunications company that will place Google balloon in certain altitude of the national air space. Google's balloon will function as Base Transceiver Station (BTS), which airs in

Endang Puji Lestari, "Rekonsepsi hak Penguasaan Atas Wilayah Udara di Tengah Kebijakan Liberarilisasi Penerbangan", Rechtsvinding Journal, Vol. 4 No. 2. August 2015, Jakarta: BPHN, page 328.

2 Agus Pramono, "Wilayah Kedaulatan Negara Atas Ruang Udara dalam Perspekktif Hukum Internasional", Masalah-Masalah Hukum, Vol. 41 No. 2, 2012, Semarang: UNDIP Law Department, page 279. the sky. ${ }^{3}$ Besides, dealing with the utilization of air space for air vehicle placement (moving vehicles operated via radar and/or earth station to keep moving within a certain time and then replaced again by the vehicle when the period is due or power out) either in practice or international regulations do not have a clear regulation yet.

Ideally, the 1944 Chicago Convention as a source of international air law only regulates civil aviation which regulates the use of aerodynamics aircraft moving point to point. Meanwhile, the Google Balloon is a vehicle that operates on the air space and static at a particular ordinate, replaced by other balloon when it runs out and serves as a satellite around an orbit by occupying $900 \mathrm{MHz}$ spectrum frequencies for Long Term Evolution (LTE) communications and is not intended to the Google Balloon/HAP (High Altitude Platform). ${ }^{4}$

There are three kinds of satellites orbit position, i.e. Low Earth Orbit (LEO): 500 to $2.000 \mathrm{KM}$ above the earth's surface, Medium Earth Orbit (MEO): 8.000 to $20.000 \mathrm{KM}$ above the earth's surface, and Geostationary Orbit (GSO): $35.786 \mathrm{KM}$ above the earth's surface. ${ }^{5}$ The Google Balloon is placed on about 20 KM in stratosphere, air space area, but it is was not regulated in 1944 Chicago Convention. Even though the functions is similar to satellite or spacecrafts but it was not regulated in the given Space Treaties or any other conventions. Thus it will be the first case of law in the world if the Indonesian government approve the Google Balloon Cooperation project.

This cooperation keeps being discussed by the parties concerned to the possibility of its

3 Amry Daulat Gultom and Diah Yuniarti, "Kajian Teknologi High Altitude Platform (HAP)", Bulletin Pos dan Telekomunikasi Kementerian Kominfo, Vol. 14 No. 2016, Jakarta; Kementerian Komunikasi dan Informatika, page 19-20.

4 A Mohammed dan Z Yang, "Broadband Communication and Application from High Altitude Platforms", International Journa of Recent Trends in Engineering, Vol. 1 No. 3, Edition of May 2009, Swedia: Department of Signal Processing, Blekinge Institute of Technology, page 239-243.

5 Djorghy Reo Angelo Bahar, "Penempatan Satelit Di Ruang Angkasa Menurut Hukum Internasional", Lex et Societas, Vol. III No. 7. August 2015, Manado: Faculty of Law Universitas Sam Ratulangi, page 63. 
realization. Apparently it is not easy to realize this cooperation due to technical aspects and its implication for national interest. The cooperation between Google Inc. (American company) with Indonesian telecommunications companies must be managed thoroughly, regarding its direct fundamental interests of the state namely sovereignty as well as other legal aspects. Therefore, this article will discuss the potential legal implications regarding to the placement of the Google Balloon over the national air space.

\section{Discussion}

The state responsibility towards national air space

National air space resource utilization has been regulated in 1945 constitution stated in its articel 33 section 3 "the earth, water, and all natural resources are controlled by the state and used to the optimal welfare of the people". The definition of being controlled by the state is that the state has the authority to manage national air space activities.

National air space is controlled (not owned) by the state by giving the authority to the government. In Indonesia, it has been a fundamental principle as it is instructed in 1945 constitution. The state has absolute responsibility to supervise and protect national sovereignty towards national air space which are manifested in the form of guidance that includes the aspect of regulation stipulation and law supervision/ enforcement. ${ }^{6}$

To apply the responsibility principles in the implementation of national air space is based on several ideas: first, realizing various regulations that are implemented in order to protect and or preserve the function of national air space effectively and sustainably; second, the implementation of strategy to overcome various weaknesses within the activity of law enforcement and the national air space management; third, these ideas can be used as reference to manifest justice, legal assurance, and or to give the benefit to people and nation in the national air space management, and fourth,

6 Agus Pramono, Op. Cit, page 287. as the fundamental effort of the funding institution establishment (insurance) to support the activity of law enforcement and the national air space management. ${ }^{7}$

Meanwhile, the implementation patterns of responsibility principles in national air space management involve: first, the implementation of particular obligation in terms of the loss due to the impact of activities; second, the implementation of certain law sanctions which is associated with the obligation for every organizers and or to overcome the risks generated, third, by giving physical sanctions, fine, or deprivation of certain rights in respect to violation and or certain crimes that are against the provisions stipulated in the management of national air space; forth, obligation charge as a closing current activity and or to recover the damages generated by activities they are responsible for; fifth, the compensation implementation in a form of compensatory, punitive, and or voluntary towards the risks generated by activities carried. ${ }^{8}$ Relying on the juridical context as referred to, it is obviously understandable and realizeable that the effort and the placement of the Google Balloon over national air space becomes an absolute authority of the state.

\section{Legal Implications Google Balloon Placement In National Air Space Area}

In 2016, Project Loon did an experiment in Indonesia, cooperated with three major mobile operators in Indonesia (Telkomsel, XL Axiata). The signing of the cooperation was conducted in Google headquarters in the United States on October 28, 2015, witnessed by Minister of Communications and Informatics. ${ }^{9}$ The placement of the Google Balloon in the national air space related to the State's interest regarding legal aspects of state sovereignty. State sovereignty is a supreme nation's interest which consists of various aspects. The upcoming fundamental legal implications in the project implementation plan of the Google Balloon is legal

\footnotetext{
7 Anonim, 2007, Naskah Akademik RUU Pengelolaan Ruang Udara Nasional, Jakarta: Pranata Pembangunan Universitas Indonesia-Pussisgan, Page 74.

8 Ibid, Page 82.

9 Amry Daulat Gultom and Diah Yuniarti, Op. Cit, page 20.
} 
aspects of the state sovereignty. In this case, it would be conducted by Lawrence Friedman's theory of the legal system and legal effectiveness theory as follows:

\section{Legal Substance Aspect}

Substance aspects regarding the Google Balloon placement is based on three (3) matters: first, Google Balloon's legal status in the provisions of law in Indonesia. At present, Google Inc. is expected to arrange partnership with Indonesian Telecommunications companies to share mobile spectrum that allows it to connect to the balloon network directly from the phones and other supporting LTE devices. This cooperation is initiated since it is difficult to run a fiber optic cable or set up a cell tower in remote areas which are usually full of mountains and forests.

Functionally, Google Balloon serves the function as communication stations that provides internet for people who live in rural and remote areas. The balloon is placed at an altitude of about 20 kilometers above the earth, so-called Project Google Loon. ${ }^{10}$ Legally Google Balloon cannot be called as an aircraft or spacecrafts. Although it is located at an altitude of 20 $\mathrm{km}$ and is double than aircrafts, according to Article IV of the 1944 Chicago Convention which states that "any machine which can derive support from the reaction of the air other than the reaction of the surface of the earth", it still utilizes air thrust for placement operation. However, seen from Google's position and function, it is static at a point a certain ordinate unlike aircraft. Hence, it can not be subject to the rules of the 1944 Aviation Civil Convention (the 1944 Chicago Convention). Similarly, the placement position in Stratosphere which is on air space layer (lowest orbit satellite is 500-2000 $K M)$, therefore their legal status is beyond the provisions referred to spacecraft as set in the given Space Treaties, which means is impossibly

10 Kanchan Kamnani and Chaitali Suratkar, "A Review Paper on Google Loon Technique", International Journal of Research In Science \& amp; Engineering, Vol. 1 No. 1 2015, India: International Journal of Research in Science and amp; Engineering, page 2. forced to submit to the the provisions of the Outer Space Treaty 1967 (OST 1967).

Secondly, legal aspects in the operation. It is necessary to determine who will act on behalf of the Indonesian government as a party of the agreement by considering that the Google Balloon project manager is the USA Company. Meanwhile the issue of Indonesian state sovereignty is the absolute responsibility of the state. Viewed from the Corporate Law, Google is a foreign company. Law Number 21 year 2013 on Outer Space and Law Number 36 year 1999 on Telecommunications stated that if a foreigner wants to operate in Indonesia, they should cooperate with the national companies. Thus it requires obvious restrictions and regulations if Google starts operating in Indonesia.

Third, the legal aspects of telecommunications system disruption. Viewed from telecommunications services, nobody can ensure the safety of the strategic and confidential telecommunications that could endanger data leak, and is apt to threats to Indonesian security because Google is a foreign party. Spectrum 900 $\mathrm{MHz}$ that is occupied from this loon project is frequency bands used for LTE in Indonesia. Till today, there is no regulation in Indonesia that regulates the frequencies use for communication systems such as Google Balloon (if any disruption of frequency systems and disturbed a communication systems including flight routes occur). The requirements for the usage of these frequencies are beyond recommendations of Radio Regulations issued by the ITU and to obtain the permission, it requires much struggle by the Indonesia government to the ITU. Likewise there is no international regulation for the Google Balloon's launch in stratosphere. In Indonesia there is Minister of Transportation Regulation Number 90 year 2015 on the Unmanned Aircraft operations Controller Air Space and uncontroller air space at an altitude of higher than $500 \mathrm{ft}(150 \mathrm{~m})$.

\section{Legal Structure Aspect}

The fundamental legal implications encountered in the implementation plan of this Google Balloon project concern with sovereign 
state to Indonesian society, especially in remote areas and likely bring real benefits including well distribution and affordable internet access throughout the archipelago.

The Google Balloon static placement in the national air space can undoubtedly be attached to other functions that Indonesia must be aware of. Whether this cooperation is approved or declined due to the national problem of defense and security, either present or future it will be at stake. Terms or other aspects to be considered in terms of function and national defense threat is that the existence of those balloons might become the extra-territorial areas of the balloon's owner.

Based on legal effectiviness theory, persistent ignorance in a certain legal fact, in this case the placement of Google Balloon, at certain points in the region of air space of sovereign state can be as occupation/territorial acknowledgment by other party (United States/ Google America) as legalized region since there is an agreement between Indonesian party and the owner of the balloon. It would be even worse when operationalization is done outside of Indonesia territory. Indonesia holds absolute authority over national air space area, and related to the interest of the vertical limit sovereign territory of air space, Indonesia holds spatial view in altitude to $110 \mathrm{~km}$, as reflected in the general elucidation of Law Number 21 year 2013 on Outer Space.

Determination of national air space vertical limits regulation as stated in explanation of outer space Act is an implementation of legal effectiveness theory on the determination of national air space vertical limits regulation because it is realized that threats level and sovereignty disturbance through national air space experienced by Indonesia keep growing over time. In contrast, Indonesia has not been able to explicitly determine national air space vertical limit on a relevant regulation or statutory. In fact, no country has determined and set on this regulation on their national law.

Because it involves the fundamental aspects of the state, then any related issues must be acknowledged and decided by the state, which means including agreement and the government decision by the consent of house of representative. ${ }^{11}$ Without approval from related institution regarding territorial interests and the agency responsible for state sovereignty in air space (The Ministry of Home Affair and the national army of Indonesia/ TNI, especially National Army of Indonesia Air Force/TNI-AU) and house of representatives, it would be incorrect and careless since the legal aspect related to sovereignty and jurisdiction is neglected. The Ministry of Home Affair and TNI-AU can question the decision and or condemn the Ministry of Communication and Information as the responsible party in telecommunication.

Other issues related to the legal structure is the territorial boundaries and law enforcement. Addressing the authority and responsibility of the state at implementing law enforcement in air space, it cannot be separated from the substance of article 33 paragraf (3) Constitution 1945. Based on this requirement, so it states "right of control by the state" over natural resources on the earth, water and the natural resources contained within (including air) and this bring the consequences to the state to use it for optimal public welfare. The meaning of article 33 paragraph (3) Constitution 1945 is that air space is a natural resource at the highest hierarchical level controlled by the state by the name of all people. ${ }^{12}$ The term "controlled " in article 33 paragraph (3) does not mean "owned" by the state, but giving the meaning of authority as an organization or state institutions to set and monitor the user for optimal public welfare.

Every state also has absolute and exclusive sovereignty on air space above the territory and limited by the rights of other state to pass in air space territory as arranged in Chicago

11 Harry P. Haryono, “Evaluasi Atas Pelaksanaan UndangUndang No. 24 Tahun 2000 Tentang Perjanjian Internasional," Jurnal Hukum Internasional, Vol. 3 No. 4, July 2006, Jakarta: The Research institute of International Law-Faculty of Law Universitas Indonesia, page 522.

12 E. Saefullah Wiradipradja, "Wilayah Udara Negara (State Air Teritory) Ditinjau dari Segi Hukum Internasional dan Nasiona Indonesia", Indonesia Journal of International Law, Vol. 6 No. 4, July 2009, Jakarta: Faculty of Law Universitas Indonesia, page 497. 
Convention 1944 and other international treaties. Article 1 states that each country has complete and exclusive sovereignty over air space of their territorial sovereignty. Therefore, air space over the territorial region of every state has the right to fully manage and control towards their own national air space. Article 5 of Law Number 1 year 2009 about flight also mentions that Indonesia has full and exclusive sovereignty over Indonesian territorial air space.

In accordance with article 10 of Law Number 34 year 2004 on Indonesian National Army, the duties of Air Force consists of carrying out military tasks in the field of defense, enforcing the law and maintaining security in the airspace of national jurisdiction in accordance with the national laws and international laws that have been ratified, duty military in the construction and development of strength air force and air defense region to implement empowerment. Based on the above provision, the Air Force is given the authority and responsibility in enforcing the law against violations of sovereignty and airspace, including prohibited airspace, restricted and hazardous areas according to their main tasks. ${ }^{13}$

\section{Legal Culture Aspect}

IT utilization can indeed provide benefits to the speed and information distribution. Yet in terms of social and cultural development of IT which is pushed by technological advances in remote areas where the people are not ready, it may generate social and cultural lag and may create gaps especially in fact that the nature of IT is limitless and full of modern technology applications.

Moreover, the absence of clear regulation would have implications on the sovereignty of the State. Thus it is necessary for discussion regarding the implementation of this agreement which shall involve the components of the state (legislature and government), not only by the Ministry of Communication and Information, in

13 Alfen Sena, 2013, Penegakan Kedaulatan dan Hukum di Ruang Udara Nasional, Jakarta: Angkasa Sena, page 11 . 16. which Telkom is a State-Owned Enterprise under the Ministry of Communication and Information.

\section{Conclusion}

The plan of implementing cooperation between Indonesia and Google (United States) will carry fundamental legal implications including: first, the aspect of legal substance that Google Balloon which will be placed in the air space of stratosphere level over national territory cannot be categorized as a air vehicle although the operation of this Google Balloon still uses aerodynamic thrust. Therefore, the provisions of national and international governing interests of flight cannot be used as a foundation and source of the law enforcement. Second, the institutional aspects/legal structure that the Google Balloon which will be at certain points in the stratosphere at an altitude of $20-50 \mathrm{~km}$, the legal aspects of national sovereignty of air space is still in the air space sovereignty of the Indonesian state. Vertical limits of national air space sovereignty of Indonesia as stated in the General Elucidation of Law Number 21 year 2013 on Outerspace is $100-110 \mathrm{KM}$. Thus, the balloon placement plan in national air space would have legal implications in the supreme national interest, namely the aspect of state sovereignty in the national air space. If then the project is approved and realized, the legal implications of territoriality aspect can emerge "territorial acknowledge to be extra-territorial" for the Balloons of Google owner state. It means by the effectiveness of "controlling area/ location" that is continuously and constantly allowed in Indonesia will result the effectiveness of legal control over the territory/location where the balloons are placed. Third is from the legal culture aspect, the law is essentially a social control, legal issues in the Google Balloon should be well addressed by upholding the national interests and therefore, to fill the legal vacuum in order to anticipate, the Indonesian government could establish SKB (Joint Decree) by involving at least four (4) ministries, which are Ministry of Communication and Information, 
Ministry of Transportation, Ministry of Politics Law and Human Rights and Airforce.

\section{Suggestion}

The issue of legal ambiguity will be the reason for the weakness of legal acts. It should be noted that any legal acts should be held as described in the principle of legality. On that basis a comprehensive interpretation of the law is needed to avoid conflicts of interest in the law, especially related to the placement of the Google Balloon over the national air space. It requires to make specific arrangements concerning the placement of the Google Balloon over the national air space so that these activities can provide assurance, fairness and legal expediency.

\section{References}

Anonim, 2007. Naskah Akademik RUU Pengelolaan Ruang Udara Nasional. Jakarta: Pranata Pembangunan Universitas IndonesiaPussisgan;

Bahar, Djorghy Reo Angelo. "Penempatan satelit di ruang angkasa menurut hukum internasional". Lex et Societatis. Vol. III No. 7. August 2015. Manado: Faculty of Law Universitas Sam Ratulangi;

Haryono, Harry P. "Evaluasi Atas Pelaksanaan Undang-Undang No. 24 Tahun 2000 Tentang Perjanjian Internasional". Jurnal Hukum Internasional. Vol. 3 No. 4. July 2006. Jakarta: The Research institute of International Law-Faculty of Law Universitas Indonesia;

Gultom, Amry Daulat dan Diah Yuniarti. "Kajian Teknologi High Altitude Platform (HAP)". Buletin Pos dan Telekomunikasi Kementerian Kominfo. Vol. 14 No. 1. 2016. Jakarta: Kementerian Komunikasi dan Informatika;

Kamnani, Kanchan dan Chaitali Suratkar. "A Review Paper on Google Loon Technique". International Journal of Research In Science and Engineering. Vol. 1 No. 1. 2015. India: International Journal of Research in Science \& amp; Engineering;

Lestari, Endang Puji. "Rekonsepsi hak Penguasaan Negara Atas Wilayah Udara di Tengah Kebijakan Liberalisasi Penerbangan". Jurnal Rechtsvinding. Vol. 4 No. 2. Edition of August 2015. Jakarta: BPHN;
Mohammed, A dan Z Yang. "Broadband Communications and Applications from High Altitude Platforms". International Journal of Recent Trends in Engineering. Vol. 1 No. 3. 2009. Sweden: Department of Signal Processing. Blekinge Institute of Technology;

Pramono, Agus. "Wilayah Kedaulatan Negara Atas Ruang Udara dalam Perspektif Hukum Internasional". Masalah-Masalah Hukum. Vol. 41 No. 2. 2012. Semarang: Faculty of Law Universitas Diponegoro;

Sena, Alfen. 2013. Penegakan Kedaulatan dan Hukum di Ruang Udara Nasional. Jakarta: Angkasa Sena;

Wiradipradja, E Saefullah. "Wilayah Udara Negara (State Air Teritory) Ditinjau dari Segi Hukum Internasional dan Nasional Indonesia". Indonesia Journal of International Law. Vol. 6 No. 4. Edition of July 2009. Jakarta: Faculty of Law Universitas Indonesia. 